\title{
Hemicrania continua associated with an unruptured anterior communicating artery aneurysm: first case report
}

\author{
Ibrahim ImamiD
}

The Editor.

Journal of Headache and Pain.

Dear Sir.

I present this 51-year-old woman who presented with a 24-month history of a gradual onset right sided headache which was continuous from the start. It was predominantly over the parieto-occipital area, the forehead and cheek, and she also had occasional sharp shooting pains over the left side of her head and neck. She had right sided photophobia but did not have nausea. The headache was associated with watering of the right eye, and occasionally blockage of the right nostril. She had not noticed any reddening of the eye. She described the headaches as disabling.

She has a history of hypertension and was on Ramipril; a temporary withdrawal did not resolve the headache. She has no relevant family history. She smokes 15 cigarettes a day but drinks alcohol only occasionally. She reported significant personal and family stress related to recent bereavement from the loss of her mother.

On examination, her right conjunctiva was slightly red. Her cranial nerves and systemic neurological examination were otherwise normal.

The clinical diagnosis of hemicrania continua was made and her headaches resolved promptly on Indomethacin but only at a dose of $50 \mathrm{mg}$ three times a day. Her magnetic resonance imaging brain scan showed an $8 \times 7 \times 9 \mathrm{~mm}$ anterior communicating artery aneurysm which was confirmed with a subsequent computed tomography angiogram

Correspondence: ibrahimimam2000@yahoo.com

Royal Devon and Exeter Hospital, Exeter, UK
(Fig. 1). Unfortunately, an attempt to treat the aneurysm interventionally was unsuccessful, and she remains on Indomethacin for control of her headache.

\section{Discussion}

This is the first case report of hemicrania continua in association with an anterior communicating artery aneurysm. The patient's history and response to indomethacin are entirely consistent with hemicrania continua. Hemicrania continua predominantly affects females and it is typically a moderately severe unilateral continuous headache which may be associated with intermittent jabs and jolts as is the case with this patient $[1,2]$.

Hemicrania continua has been reported in association with a variety of intracranial pathologies especially traumatic brain injury, sinusitis, primary and secondary brain tumours, internal carotid artery dissection, dental, orbital and temporomandibular joint problems [3, 4]. Rarer secondary causes of hemicrania continua include carotid cavernous fistula and cerebral vein thrombosis (CVT) [5, 6]. There is however only one case report of hemicrania continua in relation to an intracranial aneurysm, and this was of the internal carotid artery [7]. Cerebral aneurysms on the other hand have been reported in association with other trigeminal autonomic cephalalgias such as cluster headaches and short-lasting unilateral neuralgiform headaches with conjunctival injection and tearing (SUNCT) [8, 9].

There is a possibility that the aneurysm in this case is coincidental, unruptured aneurysms being present in $2 \%$ of the general population [10]. In this case, it was difficult to be absolutely certain of the causative 


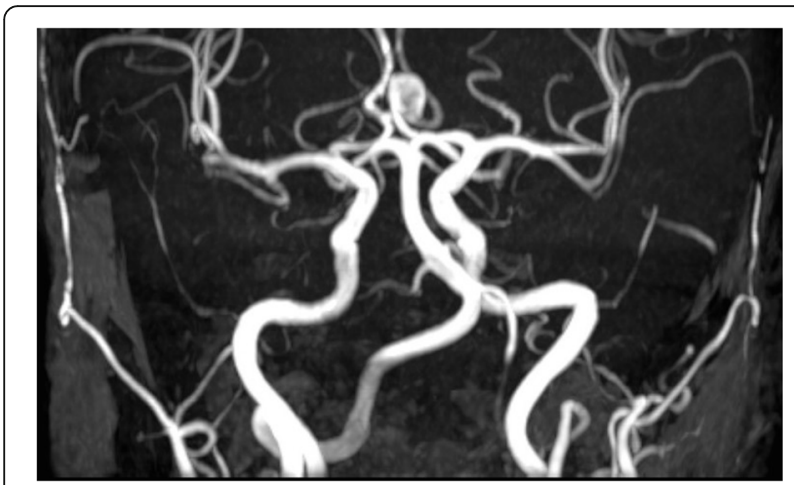

Fig. 1 Computed tomography angiogram (CTA) of the patient demonstrating the anterior communicating artery anuerysm

relationship of the aneurysm to her headache because the attempt to treat the aneurysm was unsuccessful. This case report nevertheless emphasises the importance of investigating patients with hemicrania continua for associated intracranial causes.

Yours sincerely.

Dr. Ibrahim Imam, FRCP.

Consultant Neurologist.

Neurology Department.

Royal Devon and Exeter Hospital.

Exeter.

EX1 5DH.

United Kingdom.

\section{Declarations}

I have obtained consent from the patient for publication (attached to this submission). I have no competing interests of funding conflicts to declare. My data is available for review.

Authors' contributions

The author(s) read and approved the final manuscript.

\section{Competing interests}

The author declares that he has no competing interests.

Received: 2 January 2021 Accepted: 17 February 2021

Published online: 08 March 2021

\section{References}

1. Peres MFP (2002) Hemicrania continua: recent treatment strategies and diagnostic evaluation. Curr Neurol Neurosci Rep 2:108-113

2. Silberstein SD, Peres MF (2002) Hemicrania continua. Arch Neurol 59:10291030

3. Prakash S, Patel P (2017) Hemicrania continua: clinical review, diagnosis and management. J Pain Res 10:1493-1509

4. Prakash S, Adroja B (2018) Hemicrania Continua. Ann Indian Acad Neurol 21(Suppl 1):S23-S30

5. Fiebelkorn CA, Lanzino G, Chen JJ, Brnjikji W, Eckel L, Boes CJ (2019) Carotid cavernous fistula mimicking hemicrania continua: a case report. Headache 59:1365-1369

6. Mathew T, Badachi S, Sarma GR, Nadig R (2014) Cerebral vein thrombosis masquerading as hemicrania continua. Neurol India 62:556-557

7. Vikelis M, Xifaras M, Magoufis G, Gekas G, Mitsikostas DD (2005) Headache attributed to unruptured saccular aneurysm, mimicking hemicrania continua. J Headache Pain 6:156-158

8. Valença MM, Andrade-Valença LP, Martins C et al (2007) Cluster headache and intracranial aneurysm. J Headache Pain 8:277-282
9. Cöven I, Coban G, Koyuncu G, llik KM (2013) SUNCT syndrome findings accompanied by cavernous segment aneurysm. Clin Neurol Neurosurg 115: $781-783$

10. Håberg AK, Hammer TA, Kvistad KA et al (2016) Incidental intracranial findings and their clinical impact; the HUNT MRI study in a general population of 1006 participants between 50-66 years. PLoS One 11: e0151080

\section{Publisher's Note}

Springer Nature remains neutral with regard to jurisdictional claims in published maps and institutional affiliations.
Ready to submit your research? Choose BMC and benefit from:

- fast, convenient online submission

- thorough peer review by experienced researchers in your field

- rapid publication on acceptance

- support for research data, including large and complex data types

- gold Open Access which fosters wider collaboration and increased citations

- maximum visibility for your research: over $100 \mathrm{M}$ website views per year

At BMC, research is always in progress.

Learn more biomedcentral.com/submissions 